\title{
SANGICOCCUS SP., A NEW RECORD OF PEST DEVASTATING COCONUT PALMS IN PALAWAN, PHILIPPINES
}

\author{
By \\ E.P. Pacumbaba, J.C. Orense, M.B. Zipagan, \& M.L.R. Imperial ${ }^{1}$
}

\begin{abstract}
Sangicoccus sp. nr. truncatispinus (Reyne) (Eriococcidae: Homoptera) is recorded for the first time as a major pest of coconut palms in the Philippines. It is also the first record among the coconut growing areas in the world. It sucks the plant sap resulting to chlorosis of leaves. Furthermore, honeydew droplets exuded by the pest accumulated on upper leaf surfaces become substrate for sootymolds.

The severe infestation observed in late 1980's already spread to 6 out of 8 municipalities of the southern second district of Palawan. Presently, crop losses are estimated to reach $53 \%$ of the nut yield. The prevailing easterly and westerly wind directions of $1-5 \mathrm{~m} / \mathrm{sec}$ coupled with the dense manner of planting enabled first instar nymphs (crawlers) to spread to other palms. The long dry spell also favored the proliferation of Sangicoccus sp.bv.

Controlling the spread and outbreak of this pest seems to be difficult as it thrives on eleven alternate hosts. Ant attendance contributed to dispersal and protection from natural enemies. Moreover, field population of ten predatory species remained minimal. Possible strategies for its control are presented.
\end{abstract}

\section{INTRODUCTION}

Coconut, cocos nucifera L., is a major crop in Palawan. Approximately $92 \%$ of the 4.9 million stands are in the peak of bearing stage producing an average of 88.5 MT of copra per year (PCA-Palawan Annual Report 1996). Of these bearing palms, $72 \%$ are planted in the southern district of the province. Aside from its flourishing coconut industry, Palawan is likewise considered as the country's gateway to the south, particularly to Borneo. However, this strategic location becomes a disadvantage as it serves as a bridge to pest introductions. In the early 1980's, ricefields were invaded by a foreign black bug, Scotinophara coarctata (Fabr) while the mango industry suffered a setback with the introduction of a pulp weevil, Stemochetus frigidus (Fabr). The latter was found to be endemic to Borneo (Basio et al. 1994).

In 1987, farmers in Ipilan-Mambalot area in Brooke's Point town began to notice numerous small white insects, and very thick black sooty mold accumulations on coconut leaves ( de la Chica, pers. comm.) . In 1989, infestation spread to five barangays of the same town and the occurrence of the pest, already known as mealy bug, was simultaneous with that in the municipality of Bataraza. In Rizal, the pest was only observed in mid-1990 (Aterrado, pers.comm.). By the end of 1993, the estimated infested coconut areas were 3,000,1,000 and 500 hectares in Brooke's Point, Rizal and Bataraza, respectively ( de la Chica, pers. comm.).

The alarming spread of the coconut mealybug, if left unabated, may soon result to substantial yield losses. As early as 1994, an estimated 30\% yield reduction was already reported (Pacumbaba, et al. 1996). To date, losses could have increased as the extent and magnitude of mealybug infestation grew.

\footnotetext{
${ }^{1}$ Philippine Coconut Authority-Albay Research Center, Banao, Guinobatan, Albay 4503, Philippines
} 
The Philippine Coconut Authority-Albay Research Center (PCA-ARC) in collaboration with LGU-Palawan and State Polytechnic College of Palawan (SPCP) is conducting studies for the control of the coconut mealybug to prevent its spread to other coconut- growing areas in the country. A mealybug project laboratory was established at Maasin, Brooke's Point to house the equipment, personnel and major activities of the project.

This paper reports the biological investigations undertaken to elucidate on the nature of the pest and to determine the biotic/abiotic factors influencing its incidence and spread. Possible strategies for its control are presented.

\section{MATERIALS AND METHODS}

\section{Distribution}

Seven municipalities of Southern Palawan and nearby islands were surveyed for the presence of the pest, natural enemies, symbionts and alternate hosts. Collection and preservation of the pest and associated insects were done. Specimens were identified based on available literature and were later sent to the CAB Institute of Entomology in United Kingdom for confirmation. Alternate hosts of the pest were likewise identified.

\section{Ecological Studies}

Population dynamics of the pest in the field was monitored on thirty 25-40 year old infested coconut palms each in four experimental sites in Brooke's Point and Espanola, Palawan. Monthly actual counts of insects were made on 1 sq. inch leaf area of 10 leaflets of frond No. 12 of sample palm. The number of predators, symbionts, and sootymold were recorded. Data on rainfall, temperature and relative humidity were recorded and averaged monthly.

\section{Biological Studies}

The life history, breeding and feeding habits of the pest and associated insects were studied.

\section{RESULTS AND DISCUSSION}

\section{Nature of Damage}

Sangicoccus sp. fed on the underside of coconut leaves by sucking the plant sap resulting to chlorosis (Fig.1). The damage is complicated by the insect's profuse excretion of sticky honeydew trapped by the underlying leaves which became a medium for sootymolds (Fig.2). Heavy infestation, therefore, divested palms of nutrients for growth and development while sootymold deposition interfered with photosynthesis of palms as well as understorey crops. In severely infested coconut palms, the pest was found in $77 \%$ of the crown while slightly infested palms had $30 \%$ of their fronds colonized. The pest preferred mature leaves but could survive on drying fronds. A 53\% yearly loss in crop yield was estimated in Brooke's Point and Espanola, Palawan.

\section{Pest Identity}

Mealybugs belonging to the Order Homoptera family Eriococcidae are not a well studied insect group. In the Philippines, only two endemic species are known: Eriococcus philippinensis (Morrison) on Ficus, sp. from Antique and Sangicoccus truncatispinus Reyne on Nypa fruticans from Camiguin Island (Lit 1997) Another species, E. aurocariae Maskell is most probably introduced because its only host, Aurocaria sp., is not native to the Philippines. Hitherto are the only 
felt scales recorded in our country (Lit. 1997) until an Eriococcid pest outbreak in coconuts in southern Palawan was noted in 1987.

The outbreak is the first among felt scales in Southeast Asia and also the first to be observed on coconuts. The culprit was placed under the genus Sangicoccus and was described by Watson (1996) as nearly similar to truncatispinus (Reyne) (Fig.3). It is possible that the form occurring in Palawan may be an addition to the only two known Sangicoccus species collected in rattan and coconut in New Guinea, Sulawesi Utara and Camiguin Island, Philippines in 1937 (G.W. Watson pers. comm. )

\section{Biology of Coconut Mealybug}

Life history and habits of the pest were studied in the laboratory and validated under semifield condition. The male Sangicoccus had a total life cycle of 34-65 days while the female had 79133. The latter laid up to 382 small purple eggs, borne on a common ovisac in the venter of the female. About $81-100 \%$ hatchability was observed within 10-15 days. Newly hatched nymphs moved sluggisly in search for feeding sites along or in between leaf veins, becoming established in the lamina in a straight line. The first nymphal instar or crawler was very active, mobile and could be easily wind-borne while the latter forms were sedentary. The male had two nymphal instars while the female had three. Only the male had the pre-pupa and the pupal stage. The female matured during the third instar retaining its oval form with longer mealy secretions. The male, on the other hand, became elongated and may or may not develop wings. The males had no functional mouthparts and lived only to mate, hence its short longevity. Pathenogenesis may have possibly occurred; but, it may be minimal because of the 1:17 ratio of the female to male in the field.

\section{Pest Distribution}

At present, the pest has spread to all 17 barangays of Brooke's Point, 10 out of 16 barangays in Quezon, 9 out of 22 in Bataraza, all 14 barangays of Rizal, all 9 barangays of Espanola and 7 out of 22 barangays in the town of Narra (Fig. 4). It has moved farther north to the remote barangay of Aramaywan, Quezon and Caguisan, Narra, just tow towns away from the boundary of the provincial capital, Puerto Princesa City.

The island town of Mapun, Tawi-Tawi was visited in March, 1997 to clear speculations that the pest originated from the island and was brought to mainland Palawan along with the unrestricted flow of trade. The presence of Sangicoccus sp. was confirmed in the 15 barangays of the island town. However, only few colonies of mealybug were found. Interviewed farmers related that Mapun also experienced an outbreak in the late 1950's but it gradually disappeared without application of control measure.

In Davao, Zamboanga and Albay, mealybugs closely resembling that of the Palawan species were also collected. Although the infestation is not as widespread as in the latter, this only shows that the threat of a felt scale outbreak is not limited to Palawan.

\section{Ecology}

Seasonal abundance. Low population level occurred from July to December with an average of 16 insects per sq. incb leaf area while high population of insects was noted starting January until April at an average of 29 insects per sq.-in leaf area. It was generally observed that fluctuations were correlated with rainfall. Low amount of total rainfall for the month coincided with high population level of the mealybug. Williams (1989) noticed that population of Pseudococcus spp. increased during drought conditions. He cited Fennah's report (1959) that attributed this sudden population build up to the increase in amino acid concentration in the leaves of cacao plants during drought conditions. The same could have been true in the case of coconuts. 
Sootymold was present in all infested sample palms during the 11 month sampling period. Severe incidence occurred during the months of high mealybug density. At the onset of the rainy season in May until December, sootymold decreased when washed out by heavy rains. Field population of natural enemies was relatively low throughout the sampling period. On the average, 1 insect per leaflet was recorded. Among the predators, larvae of Chrysopidae predominantly preyed on the nymphs and adults of the mealybug.

Alternate hosts. Ten plant species belonging to the three families (Palmae, Pandanaceae and Musaceae) were found alternate hosts of the coconut mealybug (Table 1). Notably, seven of these hosts were also palm species like coconut. Studies on the biological performance of the successfully established mealybug on principal and alternate hosts are on-going using suitability indicators, i.e., longevity of developmental stages, number of colonies formed, and adaptability to the hosts.

Table 1. ALTERNATE HOSTS OF SANGICOCCUS SP.

\begin{tabular}{|l|c|}
\hline \multicolumn{1}{|c|}{ FAMILY/SPECIES } & COMMON NAME \\
\hline Palmae & Butterfly palm \\
Chrysalidocarpus lutescens & Betel nut palm \\
Areca catechu & Common fan palm \\
Livistona rotundifolia & Nypa palms \\
Nypa fruticans & "Buri" palm \\
Corypha elata & Manila palm \\
Veitchia merillii & "Sago" palm \\
Metroxylon sagu & \\
Pandanaceae & Golden screw pine \\
Pandanus dubius & Fragrant screw pine \\
Pandanus amaryliifolius & Banana \\
\hline Musaceae & \\
Musa sapientum & \\
\hline
\end{tabular}

Natural enemies. Severely infested coconut palms were surveyed in search for natural enemies of the coconut mealybug. Microscopic examination of collected leaf samples disclosed no parasites and insect pathogens but four insect orders were prominently observed preying on Sangicoccus sp. (Table 2).

Table 2. INSECT PREDATORS OF SANGIOCOCCUS SP.

\begin{tabular}{|c|c|}
\hline ORDER/FAMILY/SPECIES & PREDATORY STAGE \\
\hline $\begin{array}{l}\text { Neuroptera } \\
\text { Chrysopidae } \\
\text { Ankylopteryx } s p . \\
\text { Dichochrysa } s p . \\
\text { Synthochrysa sp. } \\
\text { Hemerobiidae (unidentified) }\end{array}$ & $\begin{array}{l}\text { Larva } \\
\text { Larva } \\
\text { Larva } \\
\text { Larva }\end{array}$ \\
\hline $\begin{array}{l}\text { Lepidoptera } \\
\text { Lycaenidae } \\
\text { Allotinus } s p . \\
\text { Pyralidae } \\
\text { Conobathra aphidivora }\end{array}$ & $\begin{array}{l}\text { Larva } \\
\text { Larva }\end{array}$ \\
\hline
\end{tabular}




\begin{tabular}{|l|c|}
\hline Coleoptera & \\
Coccinellidae & \\
Cryptolaemus affinis & \\
Pseudoscymnus & Larva and adult \\
Telsimia nitida & Larva \\
Hemiptera & Larva \\
Miridae (unidentified) & Nymph and adult \\
\hline
\end{tabular}

Larvae of predaceous species of the orders Lepidoptera, Coleoptera and Neuroptera mimicked the appearance of the mealybug thereby making them oblivious to the preys. Rearing techniques for these predators were contrived to be able to study their life history, feeding and breeding habits and mass produce them.

Neuroptera. Three species of lacewings were predaceous to Sangicoccus: Ankylopteryz nr. Octopunctata (Fabr.) Dichochrysa sp. and Synthochrysa sp. Preliminary observations were focused on Dichochrysa sp. since it was often collected in the field. The eggs were green, borne on a stalk, darkening to brown as it nears hatching. The larvas had three larval instars and were all predatory to the mealybug. The larva was encased in a round silken cocoon upon pupation. The adult emerged through a circular lid opening on top of cocoon. Three larva-pupal parasites attacked this predator: Eurytoma sp. (Eurytomidae: Hymenoptera), Brachycertus nawaii (Ashmead) (Ichneumonidae: Hymenoptera) and Perilampus sp. (Perilampidae: Hymenoptera).

Lepidoptera. Larvae of two Lepidopteran species which preyed on Sangicoccus sp. Allotinus sp. (Lucaenidae: Lepidoptera) larvae were often collected in the field but emerged adults failed to mate under laboratory conditions. It was observed to be parasitized by Ooencyrtus sp. (Encyrtidae: Hymenoptera).

The brown moth, Conobathra aphidivora (Meyrick) (Pyralidae: Lepidoptera) is an Asian species also known under the genus Dipha. It was recorded from Japan, Papua New Guinea and Taiwan. Aphids were also known preys. C. aphidivora laid grainy, light brown eggs singly or in groups and the color darkens as the incubation period is expended. The four larval instars subsisted on mealybug alone. Pupae were enclosed in a cylindrical, white cocoon anchored on the underside of coconut leaves. Sometimes, a hymenopterous larval-pupal parasite, Brachymeria sp. (Chalcididae: Hymenoptera) emerged from the cocoon. This species can be artificially reared by feeding adults with honey and the immature with fresh mealybugs.

Coleoptera Pseudoscymnus sp. nr. Lewisi (Kamiya) and Telsimia nitida Chapin are generalist predators that also feed on scale insects while Crytolaemus affinis Crotch is an important predator of mealybugs worldwide. The latter beetle is also present in Papua New Guinea, northern Australia and was previously recorded from the Philippines (Booth and Hope 1986). Its origin, however, is unknown so that it cannot be determined whether it is an introduced or an indigenous species. The coccinellid group is considered to have a more significant impact to pest population since both the adult and larva were predaceous to mealybugs.

C. affinis esablished successfully in the laboratory. The egg is cylindrical, yellow in color and laid singly. The four larval instars subsisted on mealybug. Adult consumption surpassed the combined number preyed upon by the immature.

Symbionts. Dolichoderus bituberculatus Mayr, Camponotus albocinctus, Anoplolepis longines, Polyrachis sexpinos and Polyrachis sp. nobilinus were observed foraging on mealybuginfested fronds. Among the symbionts, the black ant, D. bituberculatus built nest on coconut fronds and were predominantly found attending the mealybug, in most instances to solicit honeydew. In many observations, A. longines was found to aid in the dispersal of the mealybug by carrying the eggs, nymphs and male adults in its mandible to different locations in the leaf or from frond to front 
of the same palm. Cordova (1982) observed that D. bituberculatus exhibited the same behaviour with other homopterous insects feeding on coconuts.

\section{Factors Affecting Spread of Sangicoccus sp.}

The alarming increase in mealybug population in southern Palawan indicated an ecological imbalance, which favored the pest. The biology and ecological adaptations of the pest, the nature of the host crop, and the existing climatological conditions all converged to bring about this outbreak.

The long life span, high reproductive capacity, and parthenogenetic capability of females enabled them to increase in density within a short period of time. Moreover, mealybugs were able to thrive on drying leaves and on 11 other plant species ensuring its survival even in areas with no coconut.

The presence of ant symbionts protected the mealybugs from being attacked by predators. Cudjoe et al., (1993) reported that ants in the genera Camponotus, Crematogaster and Pheidole (Formicidae: Hymenoptera) reduced parasitism rates by the exotic Epidinocarsis lopezi (Encyrtidae: Hymenoptera) to half compared to the rates observed on cassava mealybug colonies of equal size that were not attended. Colonies, which were regularly visited by ants, had little excess honeydew and individuals were evenly spaced (Cordova 1982).

The long dry season that occurred from 1989 to 1991 triggered pest outbreak in most coconut plantations. Further, the prevailing easterly and westerly wind directions with velocity of $1-5 \mathrm{~m} / \mathrm{sec}$ proved advantageous to the crawlers as wind currents carried them to other palms. This circumstance was made possible because of the closer distance and contiguous plantings of coconut in southern Palawan. Another avenue for spread is the unrestricted transport of utility roof materials using mealybug-infested coconut/nipa leaves and banana leaves as packing materials for transport of banana fruits.

Coconuts are perennial crops and stay in the field for almost a century. This provided continuous supply of food and shelter to the pest and there is no opportunity therefore for a break in the pest's life cycle enabling them to exist undisturbed.

\section{Opportunities for Control}

Studies on the biology and ecology of the pest identified key factors that might influence pest population dynamics and therefore time the application of appropriate control measures.

With the identification of indigenous insect predators, augmentative releases can be done. Natural enemies can be mass reared under laboratory conditions utilizing artificial diets. The searching behavior and the capacity to establish in the field are main characters that will form part of the impact assessment of this biological control program.

Botanical pesticides lethal to Sangicoccus are being tested in the laboratory. The minimum lethal concentration under field conditions, however, has to be investigated. Moreover, the application procedure and the effect to non-target organisms will have to be studied.

The removal of pest by leaf pruning and fertilization to enhance the productivity of the palms, are strategies that are practical and could be readily applied. 


\section{CONCLUSION AND RECOMMENDATIONS}

Sangicoccus sp. is a novel pest of coconut palm. Natural controlling factors, however, abound that may significantly influence pest populations. It is in this framework that an integrated approach is considered. Rigorous experimentation and not the piecemeal approach is needed to obtain information in appraising such strategy. These endeavors, however, have to be carried out up to field applications. A massive information dissemination campaign is also a requirement to ensure a smooth transfer of technology to end-users.

\section{ACKNOWLEDGEMENT}

The authors gratefully acknowledge the assistance of the Mealybug Project staff, LGUBrooke's Point, and PCA-Provincial Office of Palawan. The authors are also grateful to Mr. Osmundo Orense for the assistance in the preparation of the manuscript. This research forms part of the project "Integrated Control of Coconut Mealybug in Palawan", supported by the Department of Science and Technology-Philippine Council for Agriculture, Natural Resources Research and Development and the Philippine Coconut Authority.

\section{REFERENCES}

BASIO, R.G., P.J. JOHNSON, D.R. PUA, H.T. BERGONIA, L.C. DILOY and E.E. VILLEGAS. 1994. Mango pulp weevil (Sternochetus frigidus (Fabr.) (Curcullionidae: Celoptera) found in Palawan. Philip. Ent. 9 (3): 350-351.

BOOTH, R.G., and R.D. POPE. 1986. A review of the genus Cryptolaemus (Coleoptera:Coccinellidae) with particular reference to the species resembling C. montrouzieri Mulsant. Bull. Ent. Res. 76:701-717

CORDOVA, J.D. 1982. Some ants associated with some agricultural crops. B.S. Thesis, Univ. of the Philippines, Los Banos (Unpublished)

CUDJOE, A.R., P. NEUENSCHWANDER and M.J.W. COPLAND. 1993. Interference by ants in biological control of the cassava mealybug Phenacoccus manihoti (Hemiptera: Pseudococcidae) in Ghana. Bull. Ent. Res. 83:15-22

LIT.I.L. Jr. 1997. First report of the family Lecanodiaspididae and other new records and notes on Philippine Scale Insects (Coccoidea, Hemiptera). The Philipp. Entomologist. 11(2):87-95

PACUMBABA, E.P., A.R.R. ALFILER, MB. ZIPAGAN and M.L.C. REGALADO. 1994. Assessment of mealybug infestation in southern Palawan, PCA-ARC Travel Report. 30p.

Philippine Coconut Authority-Palawan Annual Report. 1996.

WATSON, G.W. 1996. Notes on the identity of the coconut mealybug from Southern Palawan. 1p

WILLIAMS, D.J. 1985. Australian Mealybugs. British Museum (Natural History), Cromwell Road, London, U.K. 431 pp. 


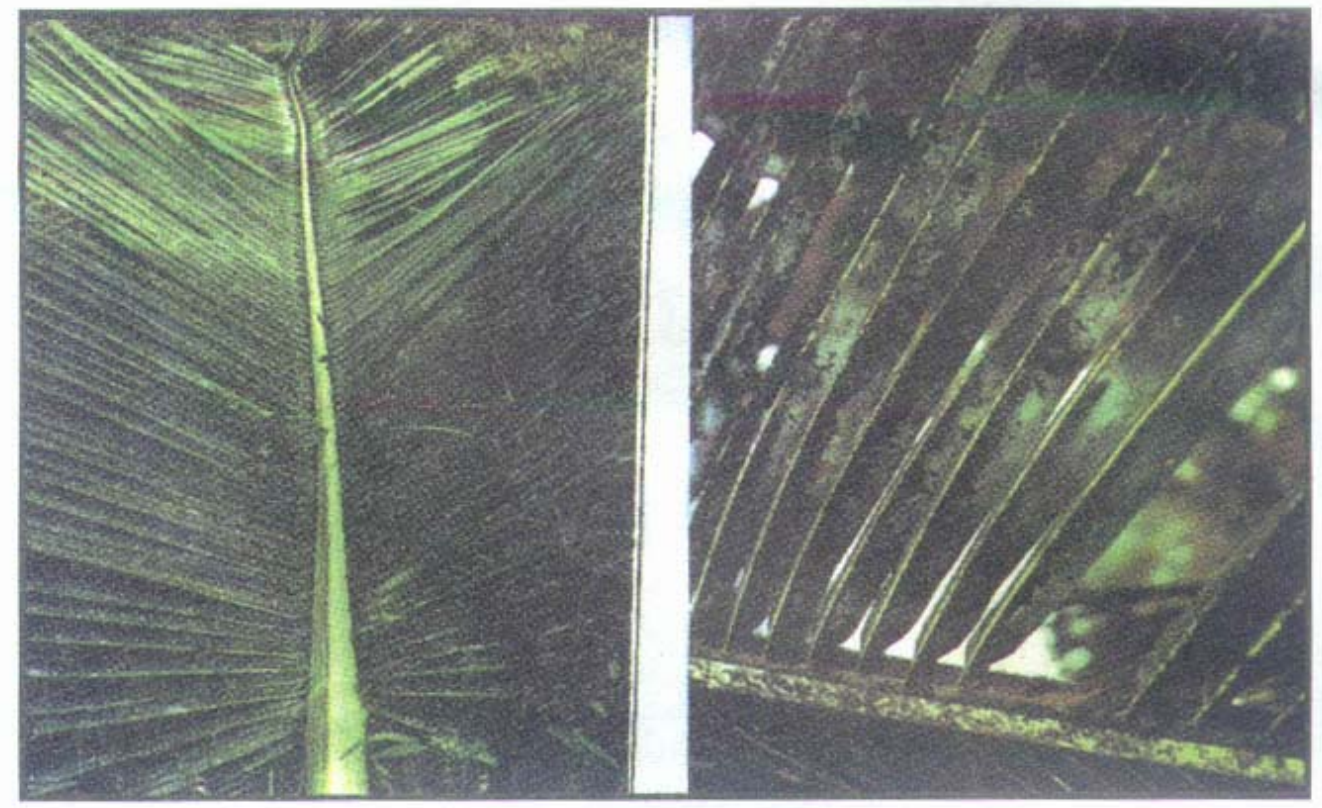

Figure 1. Dense mealybug colonies, sootymolds and chlorosis of infested leaves.

Figure 2.Development of sootymolds in leaves and rachis as a consequence of the infestation.

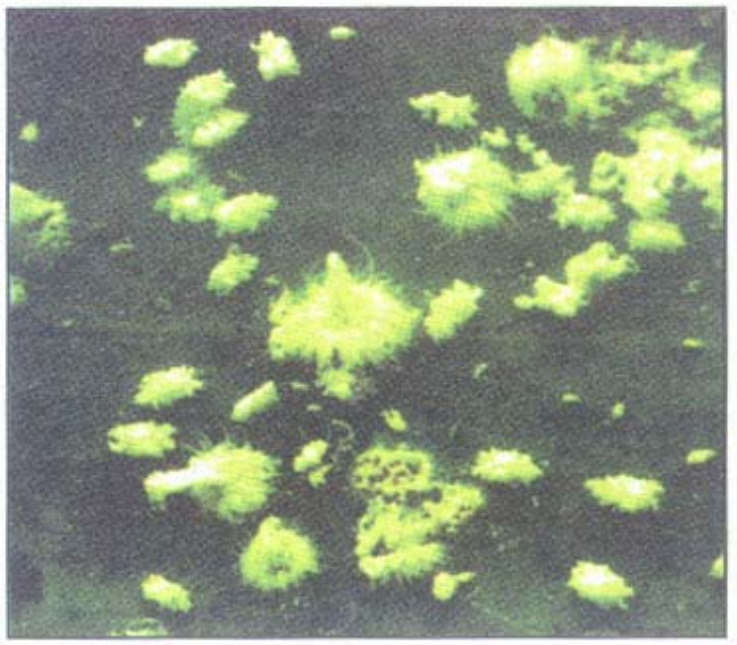

Figure 3. Mixed developmental stages of Sangicoccus sp. 


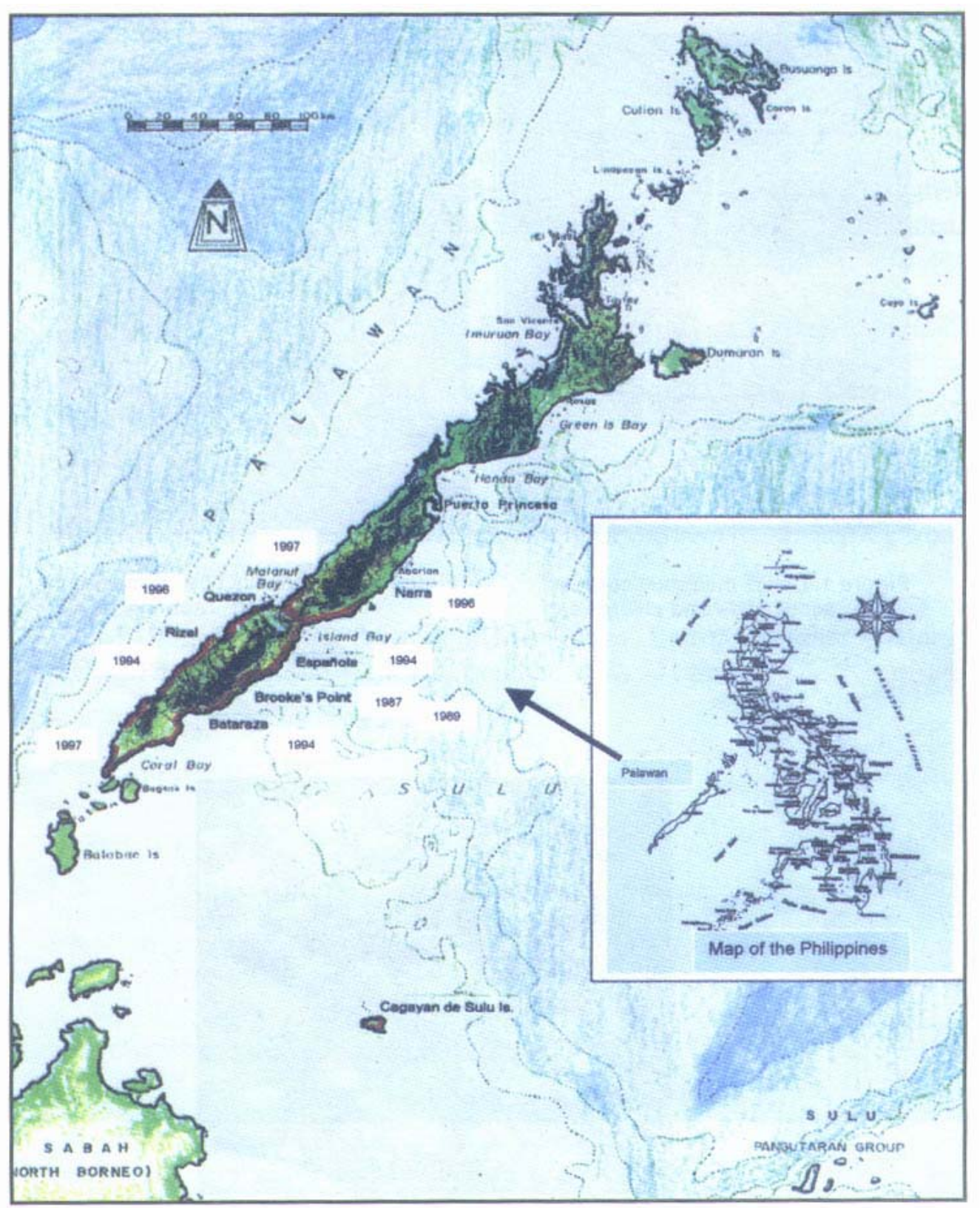

Figure 4. Distribution of Sangicoccus sp. (red shaded areas) and year surveyed in Southern Palawan, Philippines. 